\title{
Transport Service Provider Perception of Barriers and Urban Freight Policies in Brazil
}

\author{
Leise Kelli de Oliveira ${ }^{1, * \mathbb{C}}$, Carla de Oliveira Leite Nascimento ${ }^{1}$, Paulo Renato de Sousa ${ }^{2}$, \\ Paulo Tarso Vilela de Resende ${ }^{2}$ and Francisco Gildemir Ferreira da Silva ${ }^{3}$ (D) \\ 1 Department of Transport and Geotechnical Engineering, Universidade Federal de Minas Gerais, \\ Belo Horizonte 31515-212, Brazil; carla.oln@gmail.com \\ 2 Research and Development Center for Logistics, Supply Chain and Infrastructure, Fundação Dom Cabral, \\ Nova Lima 34018-006, Brazil; paulorenato@fdc.org.br (P.R.d.S.); pauloresende@fdc.org.br (P.T.V.d.R.) \\ 3 Economy Graduate Program, Universidade Federal do Ceará, Fortaleza 60020-60, Brazil; gildemir@ufc.br \\ * Correspondence: leise@etg.ufmg.br
}

Received: 30 October 2019; Accepted: 30 November 2019; Published: 4 December 2019

check for updates

\begin{abstract}
The aim of this paper is to analyze the perceptions of the transport service providers on the barriers in urban freight transport and the restrictions imposed on freight vehicles, identifying which urban freight transport policies can improve this activity in Brazil. Principal component analysis allowed us to identify which are barriers in urban cargo transport and the restrictions imposed on freight vehicles. In addition, we evaluated freight policies that can improve the activity using probabilistic preference. We obtained the database from a web-based survey of transport service providers in Brazil. The results indicate that the urban freight vehicle restriction is related to congestion and availability of loading and unloading areas. The freight vehicle restriction is a result of the lack of information and data. The theft of cargo significantly impacts urban freight transport. Transport service provider company perceptions indicate an urban mobility plan as the most-required freight policy to improve freight mobility. To reduce the barriers to urban freight planning, an understanding of the problem involving the stakeholders is needed. To do so, the challenge is to change the culture in the transportation planning process by integrating various actors to create an urban logistics plan that generates opportunities for the city.
\end{abstract}

Keywords: urban freight transport; transport service provider companies; principal component analysis; probabilistic preference; urban logistics plan

\section{Introduction}

Since the late 2000s, social, economic, and technological transformations, reclassifications in urban land use, and the environmental consequences of road-based transport systems have significantly changed the patterns of freight movements and have increased the interest in urban freight transport [1]. The growth in urban population and, consequently, the increase in the rate of consumption pose challenges for cities to achieve sustainable urban freight transport. In general, congestion is present in most cities around the world. In Latin American cities, congestion is a direct result of the current mobility model, based mostly on the use of private vehicles due to the low quality of the public transportation system (in most cities). In this context, the logistics operator experiences difficulties when performing urban deliveries. In the Brazilian context, the freight activities are only viewed as a private business with negative impacts on the city. This view needs to be changed to implement efficient freight public policies to reduce the negative effects of urban deliveries. Thus, we intend to contribute to this shift in paradigm. 
Urban freight transport (UFT) is usually recognized for its unsustainable impacts on the quality of life in cities, including social, economic, and environmental problems (traffic congestion, air pollution, and noise pollution) [2,3]. A summary of the current state in Brazil can be described as follows: $86 \%$ of the population live in urban areas [4], which is estimated to reach $91.1 \%$ by 2050 [5], the world population living in urban areas being $54.83 \%$ and expected to reach $68 \%$ by 2050 ; the transport sector in Brazil was responsible for $44.8 \%$ of $\mathrm{CO}_{2}$ emissions in 2014 [4].

Besides these problems, UFT plays a policy role in the economic development of a city, in sustaining the population's way of life, and in the maintenance and competitiveness of industrial and commercial activities, as it is a necessity for economic exchanges between spatially dispersed locations [6-10]. This situation has occurred because "freight does not vote like people do" [11] (p. 189). Besides, freight transport plays a minor role in transport planning procedures and policymaking in most cities [12].

As such, obtaining information on urban freight transportation and how to best influence it is essential to minimize its negative externalities, without harming the economy or quality of life. UFT management is often hindered by a lack of awareness, not only in the local regulatory context, but also regarding the acceptability and operative constraints of the various stakeholders (freight carriers, local policymakers, and retailers). The lack of participation of the stakeholders in public policymaking prevents the practical implementation of initiatives and measures.

Considering the context of urban freight transport, logistics operator, and freight policies, despite the number of papers published, studies are lacking in Brazil. Moreover, it is this deficiency that motivated us to perform the analysis presented in this paper.

In this way, our objective is to analyze the perceptions of the transport service provider companies on the barriers encountered by them, and also their opinions on the quality of the urban freight policies in Brazil. We identified the barriers to urban freight transport and cargo vehicle restrictions using principal component analysis (PCA). Urban freight policies were evaluated using an entropy measure of preferences.

While European and North American countries discuss the engagement of stakeholders, some developing countries such as Brazil analyze how to overcome the barriers to improve urban freight transport by an open dialogue between the stakeholders on urban freight policies. This paper outlines the perceptions of the Brazilian transport service provider companies to contribute to public policies to improve urban mobility.

Considering the difficulties of the Brazilian government (and those of other Latin American countries) experience in obtaining data on urban freight transport, the results of this paper provide practical information to propose urban freight policies based on the experience of transport service providers. If the policies consider the vision of the stakeholders, they are more likely to succeed when implemented. Thus, we contribute to the literature on stakeholder perceptions in order to create a useful public policy for urban freight transport, based on challenges faced by practitioners and also by considering the complications experienced when implementing public policies in Brazil. Also, this study differs from others due to the discussion on the implication of public policies and political issues in the Brazilian context.

Finally, we used two methods rarely used in urban freight transport literature: PCA and the entropy measure of preferences. The combination of PCA and the k-means cluster method is used to identify: (1) a cluster of cities considering the spatial organization, economic profile, and influence on urban distribution [13]; (2) the logistics criteria used to compose a decision-making tool [14]; (3) a logistics cluster in São Paulo [15]; (4) motivations and barriers to collaboration in urban logistics in Singapore [16]; (5) a selection of cities to conduct an urban goods transport survey, using an example of Parisian municipalities [17]; and (6) urban truck driver activity patterns [18].

The remainder of this paper is structured as follows: Section 2 presents a literature review on stakeholders' perception, including a subsection on this perception in Brazil. Section 3 outlines the research approach. Section 4 presents the results and discussion, and Section 5 presents the conclusion that includes recommendations for future research. 


\section{Literature Review}

Some scholars have examined the relationship between the stakeholders' perceptions and public UFT policies. A literature review of the interaction between stakeholders in city logistics planning was reported [19]. We reviewed the literature to identify the stakeholders' perceptions of urban freight transport. The results of the literature review were classified based on the focus of this study, stakeholders involved, and research method. Considering the focus of the paper, the scholars analyzed:

(1) Freight policies [8,10,20-35];

(2) Barriers to urban freight considering the perception of stakeholders [10,21,35];

(3) Engagement of stakeholders in urban freight transport [23,36,37];

(4) The behavior of stakeholders within urban freight transport policies [37,38];

(5) Participation of the stakeholders in the decision-making process [34,36];

(6) Planning processes [33,36]; and

(7) Participation in the policymaking process [23,36].

Scholars considered some stakeholders in these papers:

(1) Transport providers $[8,20,24,27-31,33,38]$;

(2) Retailers $[8,10,24,27-31,33,35,38]$;

(3) Local authorities $[8,23,24,26-28,31-34]$; and

(4) Shippers $[29,31]$.

The scholars wanted to understand the relationship between the stakeholders' perceptions and public UFT policy using:

(1) Quantitative analysis [10,24,26,30,32];

(2) Discrete choice modelling [20,23,36,37];

(3) Multi-criteria analysis $[8,29,31,33,34]$;

(4) Agent-based modelling [23,35,38]; and

(5) Ex-ante assessment [22,39].

The literature review led us to some conclusions: (1) the freight policies analysis is recurrent in the literature; (2) the literature considered the transport providers, retailers, local authorities, and shippers as stakeholders in their analyses; and (3) we did not identify a common method used to analyze the stakeholder's perception, with quantitative analysis being the most common. Gatta et al. present a review of the methods used to analyze stakeholder preferences [33].

\section{Urban Freight Transport and Stakeholders in Brazil}

In Brazil, the UFT planning is still developing. The Federal Law 12.587/2012 [40] establishes the obligation to create urban mobility plans in cities with more than 20,000 inhabitants. The cities must consider the characteristics of the modes of transport in their planning, and the infrastructure must allow the movement of people and cargo. Despite this requirement, data explaining the urban freight transport system in Brazilian cities remain scarce. Similarly, Brazilian municipalities struggle to incorporate cargo into urban mobility plans due to the lack of knowledge in the area [26].

To change this situation, some Brazilian researchers have investigated the involvement of stakeholders in the UFT policies. Stakeholders' perceptions (population, carriers, retailers, and representatives of the municipal government) regarding urban freight distribution and city logistics solutions in Belo Horizonte (Brazil) were reported [24]. We aim to understand the different perspectives and underlying paradigms to identify challenges and solutions to urban freight distribution. In the same context, Oliveira et al. examined the viewpoint of different stakeholders (industries, carriers, and retailers) from large enterprises in Brazil on urban freight transport problems, city logistics solutions, and current practices [30]. They compared the effectiveness of city logistics solutions 
considering the viewpoint of these stakeholders to determine whether stakeholders' stated opinions match their actions and if solutions can be identified that consider these viewpoints.

Also, Oliveira et al. analyzed the urban freight transportation in nine Brazilian cities with different demographic, economic, and morphological characteristics [10]. Data from 1882 commercial establishments were used to discuss problems and solutions for urban freight transport from the retailers' point of view. Data collected in commercial establishments in six cities from Brazil's Minas Gerais state (Betim, Belo Horizonte, Contagem, Divinópolis, Itabira, and Nova Lima) were used to identify the problems and solutions for urban freight transportation from the retailer's point of view [35]. The authors aimed to verify if any similar problems and solutions exist throughout these cities. Finally, Furquim et al. examined the differences and disagreements in the delivery and receipt of goods, from the viewpoint of the retailers and transporters operating in the urban center of Sorocaba [28]. They also identified the local restrictions on vehicle cargo movement and the challenges with this operation.

Considering the results of the literature review and the reality in Brazil, we conclude that research gaps exist in stakeholder perception. We observed that few methods were used in the previous analyses. Thus, we contribute to the understanding of the UFT problem in Brazil. To the best of our knowledge, this is this first time the research methods used in this paper, PCA and probabilistic preference, were used for the analysis of urban freight transport, which is another contribution of this article to the literature.

\section{Research Approach}

We conducted a survey of Brazilian transport service provider companies. The questionnaire included 5 blocks (Table 1 ) that gathered data about the company (Block 1), urban delivery processes (Block 2), e-commerce deliveries (Block 3), barriers related to urban freight transport and freight restriction measures (Block 4), and urban freight policies (Block 5). The questionnaire design is presented in Table 2. Some barriers addressed in the survey are specific to the Brazilian context, such as cargo theft and robbery (Block 4). We used a 5-point Likert scale: not very important (1), not important (2), neutral (3), very important (4), and extremely important (5), to evaluate and measure the freight restriction barriers. We highlight that freight restriction is a common public policy in Brazilian cities, in general, implemented to improve urban mobility without evaluation of the efficacy of the measure.

The urban freight policies presented in Block 5 were selected from the following literature: implementation of an urban mobility plan [12], loading/unloading areas [41,42], mini-hubs in urban areas [43-46], electrical vehicles [47-50], cargo bikes [51-54], truck lanes [55], off-peak deliveries [56-58], freight delivery restriction [59,60], congestion charge [61], pick-up points or lockers [62,63], and collaborative delivery [36,64].

The survey was administered via the Internet, where the questionnaire was sent to 5205 Brazilian transport service provider companies. These companies are part of the database of one of the most important business schools in Brazil. We obtained responses from 202 companies in Brazil between July and August 2018.

Figure 1 presents the design of the research approach used to analyze the data. In order to depict the characteristics of companies' respondents, we used the measure of central tendency and spatial tools to identify their location. 


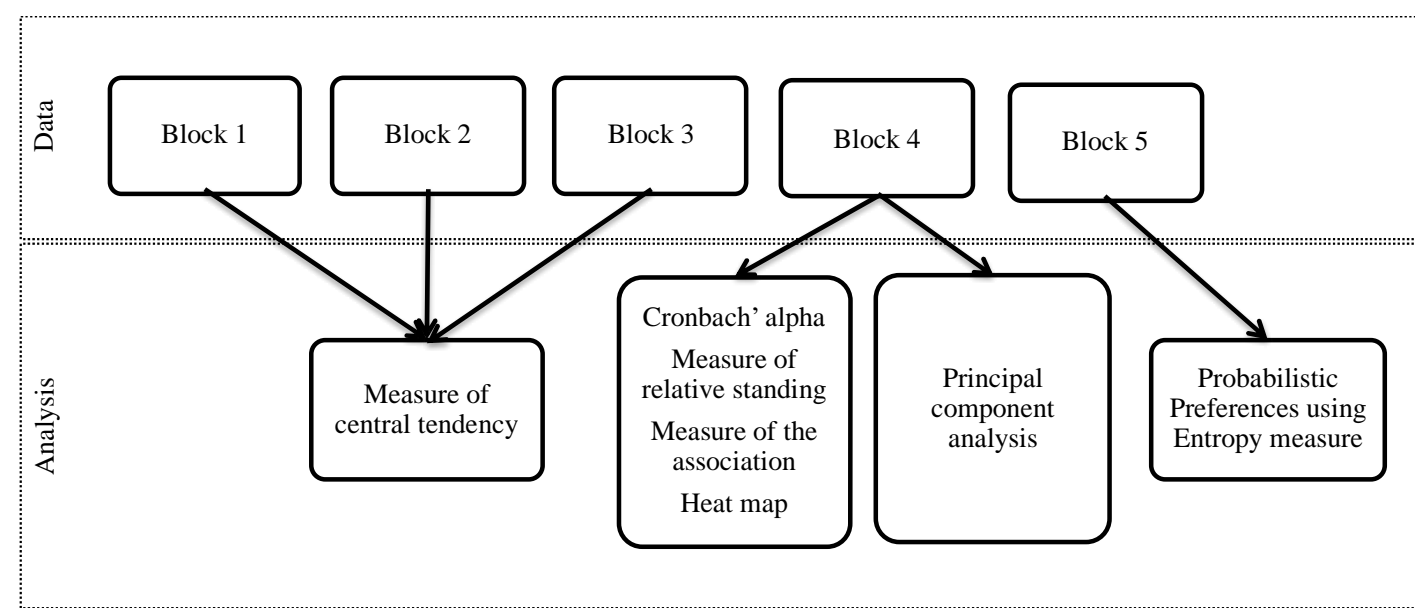

Figure 1. Design of the research approach.

Table 1. Survey questionnaire design.

\begin{tabular}{|c|c|c|c|}
\hline Block & Theme & Variable & Response Type \\
\hline Block 1 & $\begin{array}{l}\text { Company } \\
\text { information }\end{array}$ & $\begin{array}{c}\text { City/state } \\
\text { Gross sales } \\
\text { Number of employers }\end{array}$ & $\begin{array}{c}\text { Text } \\
\text { Categorical (10 classes) } \\
\text { Continuous }\end{array}$ \\
\hline Block 2 & Urban delivery & $\begin{array}{c}\text { City } \\
\text { Type of vehicles } \\
\text { Main class of product delivered } \\
\text { Fleet owner }\end{array}$ & $\begin{array}{l}\text { Categorical (19 classes) } \\
\text { Categorical (6 classes) } \\
\text { Categorical (10 classes) } \\
\text { Categorical ( } 3 \text { classes) }\end{array}$ \\
\hline Block 3 & $\begin{array}{l}\text { E-commerce } \\
\text { deliveries }\end{array}$ & $\begin{array}{l}\text { \% home deliveries } \\
\% \text { failure home deliveries } \\
\text { Alternative from home deliveries }\end{array}$ & $\begin{array}{c}\text { Continuous } \\
\text { Continuous } \\
\text { Categorical (3 classes) }\end{array}$ \\
\hline \multirow{2}{*}{ Block 4} & Barriers & $\begin{array}{c}\text { Restriction of freight vehicles } \\
\text { Congestion } \\
\text { Availability of loading/unloading areas } \\
\text { Signaling of loading/unloading areas } \\
\text { Theft of goods } \\
\text { Delivery time from e-commerce products } \\
\text { Home deliveries failure }\end{array}$ & Likert scale \\
\hline & $\begin{array}{l}\text { Freight restriction } \\
\text { barriers }\end{array}$ & $\begin{array}{c}\text { Lack of information } \\
\text { No planning procedure } \\
\text { Lack of data } \\
\text { Impact on the distribution cost } \\
\text { Implementation of an additional fee } \\
\text { Environmental impact } \\
\text { Involvement of stakeholders }\end{array}$ & Likert scale \\
\hline Block 5 & $\begin{array}{l}\text { Urban freight } \\
\text { policies }\end{array}$ & $\begin{array}{c}\text { Urban mobility plan } \\
\text { Guidelines to loading/unloading areas } \\
\text { Booking loading/unloading areas in advance } \\
\text { Mini-hubs in urban areas } \\
\text { Electric vehicles } \\
\text { Cargo bikes } \\
\text { Truck lanes } \\
\text { Off-peak delivery } \\
\text { Freight vehicle restriction } \\
\text { Congestion charge to freight vehicles } \\
\text { Pick-up points or lockers } \\
\text { Collaborative delivery }\end{array}$ & Ranking \\
\hline
\end{tabular}


Table 2. Descriptive analysis and Cronbach's alpha results from Block 4 questions of the survey (Qu., quartile).

\begin{tabular}{|c|c|c|c|c|c|c|c|}
\hline Theme & Variable & Min & 1st Qu. & Median & 3rd Qu. & Max & Cronbach's Alpha \\
\hline \multirow{7}{*}{ Barriers } & Restriction of freight vehicles & 1 & 5 & 5 & 5 & 5 & 0.72 \\
\hline & Congestion & 3 & 5 & 5 & 5 & 5 & 0.72 \\
\hline & Availability of loading/unloading areas & 3 & 5 & 5 & 5 & 5 & 0.70 \\
\hline & Signalling of loading/unloading areas & 1 & 4 & 4 & 4 & 5 & 0.75 \\
\hline & Theft of goods & 3 & 5 & 5 & 5 & 5 & 0.74 \\
\hline & Delivery time of e-commerce products & 1 & 4 & 4 & 4 & 5 & 0.74 \\
\hline & Home delivery failures & 1 & 5 & 5 & 5 & 5 & 0.73 \\
\hline \multirow{7}{*}{$\begin{array}{l}\text { Freight } \\
\text { restriction } \\
\text { measure }\end{array}$} & Lack of information & 1 & 4 & 4 & 4 & 5 & 0.71 \\
\hline & No planning process & 1 & 5 & 5 & 5 & 5 & 0.72 \\
\hline & Lack of data & 1 & 4 & 4 & 4 & 5 & 0.70 \\
\hline & Impact on the distribution cost & 1 & 4 & 4 & 4 & 5 & 0.76 \\
\hline & Additional fee & 1 & 4 & 4 & 4 & 5 & 0.71 \\
\hline & Environmental impact & 1 & 4 & 4 & 4 & 5 & 0.70 \\
\hline & Lack of involvement of stakeholders & 1 & 4 & 4 & 4 & 5 & 0.73 \\
\hline
\end{tabular}

Cronbach's alpha was used to measure the internal consistency of the variables in Block 4 . Cronbach's alpha is a measure of the internal consistency of a scale, expressed as a number between 0 and 1 [65]. Internal consistency "means that all items in a test measure the same concept" [65] (p. 53).

Relative standing (minimum, 1st quartile, median, 3rd quartile, and maximum) was calculated to understand the perception of the companies on the issues evaluated. The measure of the association (Spearman correlation) was used to identify which barriers and restriction issues are more relevant. These results are presented using Corrgram [66]. We used a heat map to show the Brazilian cities where urban distribution is a barrier due to restrictions and cargo theft. A heat map illustrates the concentration of a phenomenon in space [67].

PCA was used to identify dependent variables. Firstly, we measured the suitability of the data for PCA using Kaiser-Meyer-Olkin (KMO) [68]. A value above 0.7 is considered median, and above 0.8 is considered acceptable for the KMO test [68]. Considering the sample characteristics for analysis, we used the eigenvalues to determine the number of principal components [69]. An eigenvalue greater than 1 indicates that the component accounts for more variance than accounted for by one of the original variables. This is used as a cut-off point to identify components to retain, which is valid to standard data. The total variance and analysis of the scree plot is another method to limit the number of components. A scree plot is a plot of eigenvalues ordered from largest to the smallest. The number of components is determined at a point beyond which the remaining eigenvalues are all small $[70,71]$. In this study, we considered the eigenvalues ordered from largest to smallest to determine the number of components. More details on PCA have been previously reported [71].

A circle of correlation was used to identify the correlation between a variable and a principal component (PC) using the coordinates of the variable on the PC. The results are interpreted as: (1) positively correlated variables are grouped together, (2) negatively correlated variables are positioned on opposite sides of the plot origin (opposing quadrants), and (3) the distance between variables and the origin measures the quality of the variables on the factor map. The squared loading for variables is called $\cos 2$, which measures the quality of the representation of the variables. We present these results using a correlation circle. A high $\cos 2$ value indicates a good representation of the variable on the PC, and, in this case, the variables are positioned close to the center for the correlation circle. $\cos 2$ is represented using colors in the correlation circle: red represents high values of $\cos 2$, blue represent variables with mid-range $\cos 2$ values, and white represents variables with low $\cos 2$ values. Considering these steps, the pattern of similarity between the factors affecting barriers related to urban freight transport and the freight restriction measure was identified. 
Finally, we identified the freight policies from Brazilian transport service provider companies using the aggregated decision. In the first step, we measured the information entropy associated with each possible freight policy using Shannon's entropy. This method is described by [72].

The second step was computing the score and rank of each individual preference using the weighting obtained in the previous step. Finally, the third step was computing the rank to represent the aggregate rank. We computed the median of rank variable using the CPP.SAW.ENTROPY command and Mode as the aggregation decision using the CPP package in R (R Foundation, Wien, Austria). From this analysis, we obtained an ordered preference of the freight policy.

We performed the analysis using R software v.1.1.463 (R Foundation, Wien, Austria) using packages Corrgram [73], psych [74], MAAS [75], FactoMineR [76], and CPP [77].

\section{Results and Discussion}

The gross revenue of Brazilian transport service provider companies responding to the survey was equivalent to $14.89 \%$ of the current value of the transport, storage, and post subsector at market prices in 2017. The headquarters of the companies were located in 94 cities in $81 \%$ of the states in Brazil (Figure 2a) and performed urban deliveries in many Brazilian cities (Figure 2b). The fleet dedicated to these deliveries was mixed (owned and outsourced, $84.2 \%$ ), owned $(6.4 \%)$, or outsourced $(9.4 \%)$. The vehicles in the fleet were classified as less than $1 \mathrm{t}(6.4 \%), 1$ to $4.9 \mathrm{t}(35.5 \%), 5$ to $10 \mathrm{t}$ $(35.5 \%)$, and greater than $10 \mathrm{t}(22.1 \%)$. One company (0.5\%) performed deliveries using bicycles in 18 Brazilian cities.

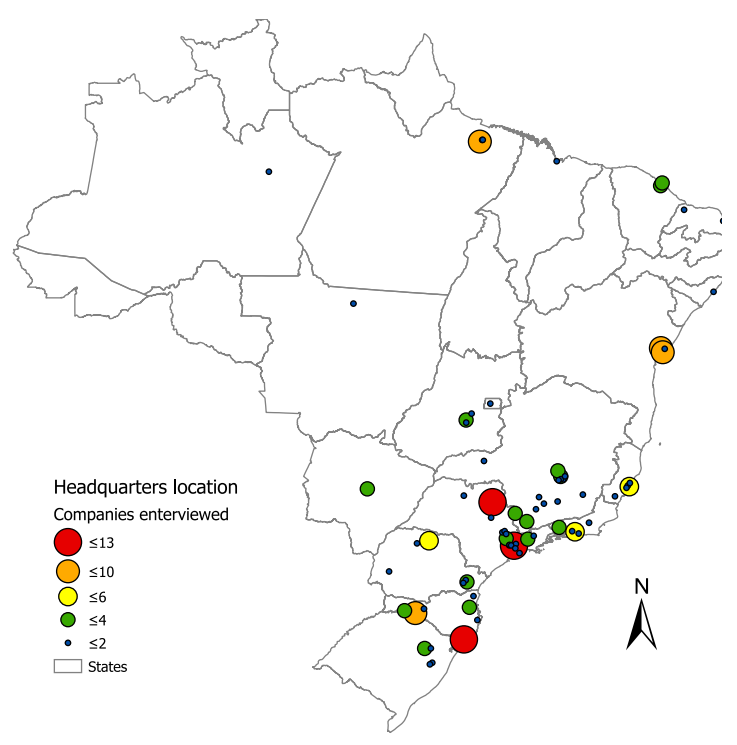

(a)

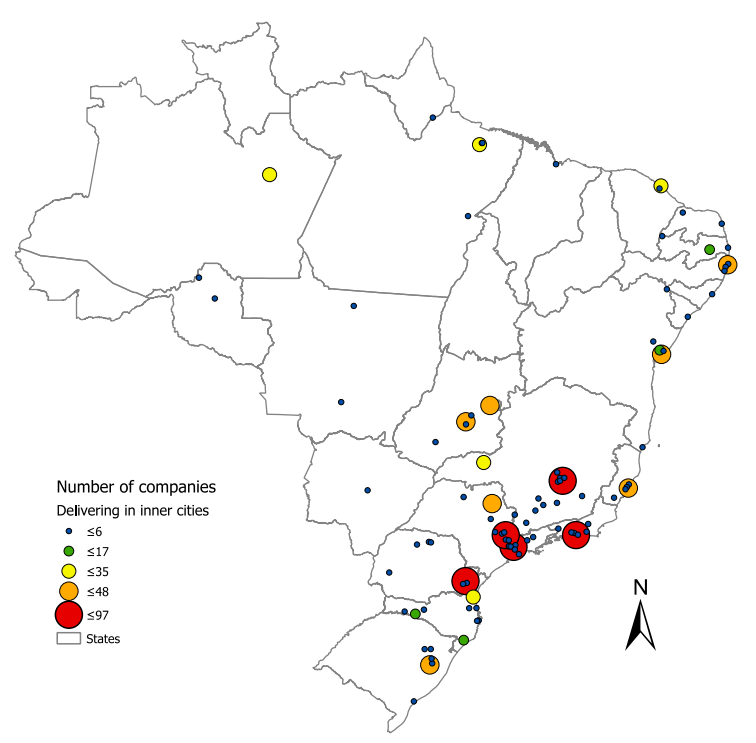

(b)

Figure 2. (a) Location of headquarters of Brazilian transport service provider companies interviewed, and $(\mathbf{b})$ regions in which these companies perform urban deliveries.

The descriptive statistics of the characteristics of the companies (revenue, number of employees, and products delivered) are presented in Figure 3. Small companies ( $<50$ million Real of gross billing) were the majority of the sample (Figure $3 \mathrm{a}$; USD $1 \approx$ BRL 4 ). The number of employees ranged from 3 to 20,000 (Figure 3b). Electronics and home appliances were the main products delivered (Figure 3c). These data show that the companies delivered goods in the different regions of Brazil and, especially, in the large urban centers of Brazil. 


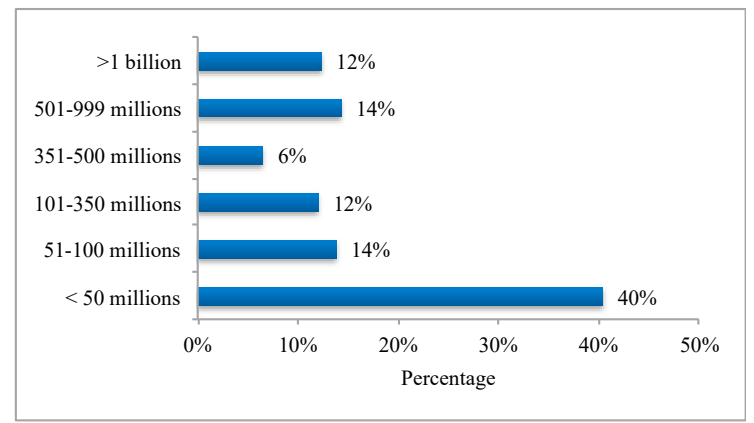

(a)

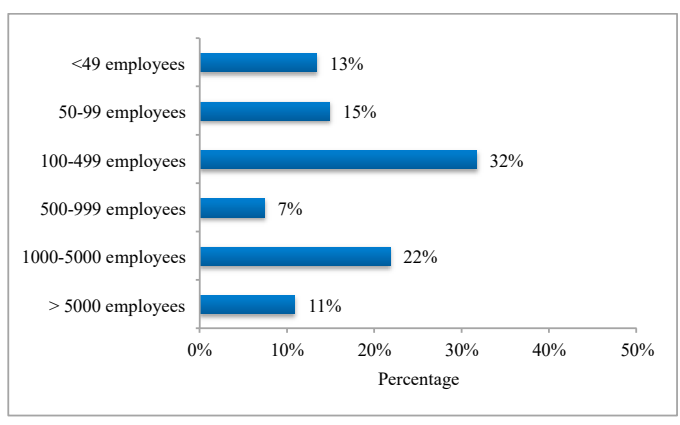

(b)

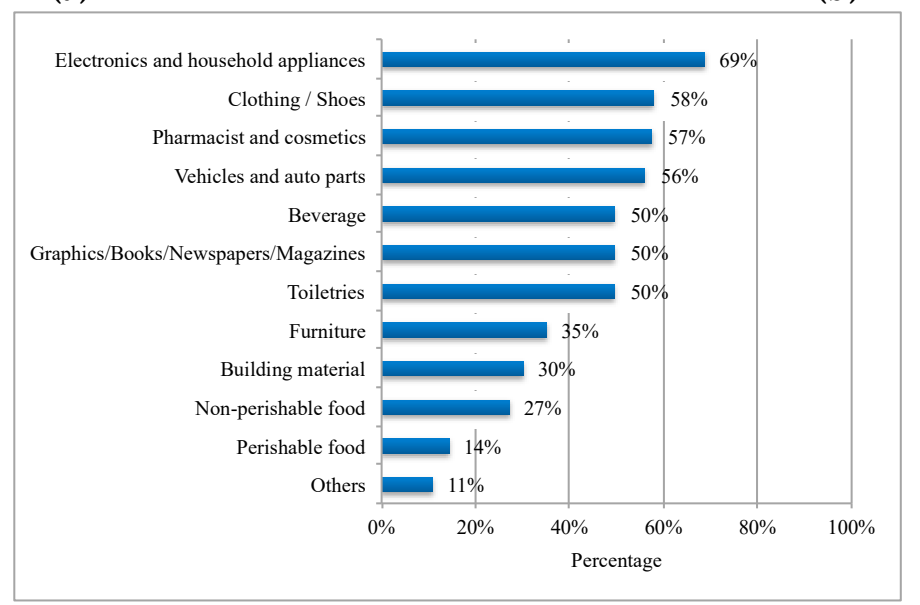

(c)

Figure 3. (a) Revenue, (b) number of employees, and (c) products delivered of the surveyed companies in Brazil.

The reliability of the sample was evaluated using Cronbach's alpha (Table 3) since the data came from Likert scale questions. The results showed that the internal consistency of the questionnaire is acceptable [78] since the values ranged from 0.70 until 0.76. The KMO test result was 0.71, which is considered an acceptable result [68]. Considering these outcomes, we used these variables to perform PCA.

Table 3. Eigenvalues and the proportion of variance of each principal component (PC).

\begin{tabular}{ccccccc}
\hline \multirow{2}{*}{ PC } & \multicolumn{2}{c}{ Eigenvalue } & \multicolumn{2}{c}{ Variance Percentile } & \multicolumn{2}{c}{ Cumulative Variance Percentile } \\
\cline { 2 - 6 } & Barriers & Restriction & Barriers & Restriction & Barriers & Restriction \\
\hline 1 & 3.17 & 3.17 & 45.28 & 42.28 & 45.28 & 42.28 \\
2 & 1.23 & 1.23 & 17.58 & 17.58 & 62.86 & 59.86 \\
3 & 0.93 & 0.93 & 13.24 & 13.24 & 76.10 & 73.10 \\
4 & 0.65 & 0.65 & 9.29 & 9.29 & 85.87 & 82.39 \\
5 & 0.45 & 0.45 & 6.48 & 6.48 & 91.87 & 88.67 \\
6 & 0.34 & 0.34 & 4.88 & 4.89 & 96.75 & 93.76 \\
7 & 0.23 & 0.22 & 3.25 & 3.24 & 100.00 & 100.00 \\
\hline
\end{tabular}

A descriptive analysis of Block 4 variables is also presented in Table 2. In general, the respondents considered the barriers extremely important (first quartile and median with minimum values of four), except the signaling of loading/unloading $(\mathrm{L} / \mathrm{U})$ areas. All the variables related to freight restriction measures were considered as important, except for no planning process considered as extremely important. These results indicate that all variables in this block require some attention from local authorities in the development of freight policies to reduce the impacts on and of this activity. As an 
example, in Rio de Janeiro, freight vehicle restriction was implemented in 2016. The movement of freight vehicles is forbidden in the city center from 06:00 to 21:00. However, this city experiences recurrent theft of goods (an additional fee for delivery is applied in some regions in Rio de Janeiro). As such, this freight policy directly impacts the delivery process in this city, increasing transportation costs.

The correlation between the variables in Block 4 is presented in Figure 4. The availability of L/U areas is correlated with congestion. A moderate correlation exists between restrictions on freight vehicles and (1) availability of L/U areas and (2) congestion. Home delivery failures are correlated with (1) freight vehicle restrictions, (2) availability of L/U areas, (3) congestion, and (4) theft of goods. Some of these results are easily explained-the restriction on freight vehicles causes two phenomena in Brazilian cities: the drivers arrive early (before the restriction time) and park in L/U areas; or, less commonly, start the delivery process before the restriction time. However, in some cities, like São Paulo, the restrictions include time and upper limits of vehicle size, resulting in more freight vehicles performing deliveries and contributing to congestion.

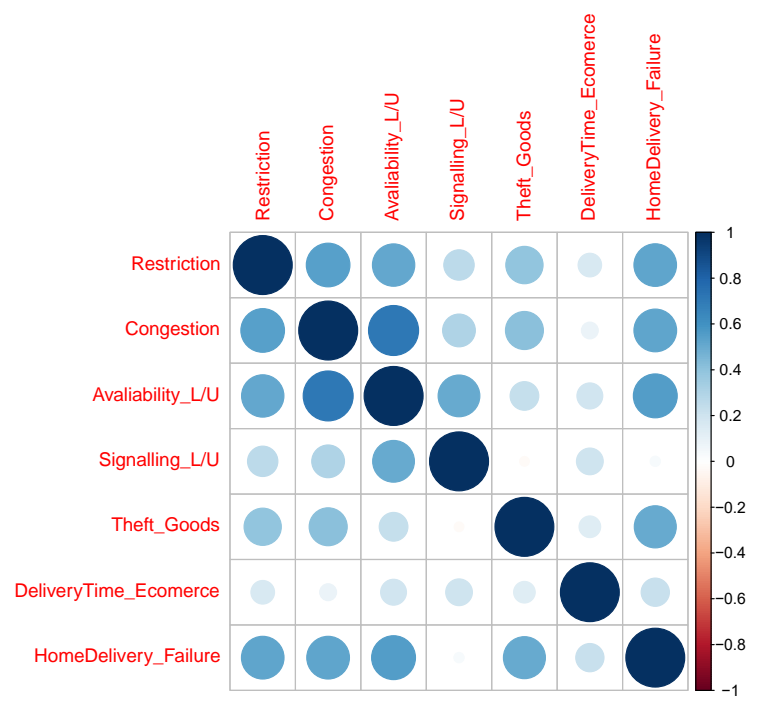

(a)

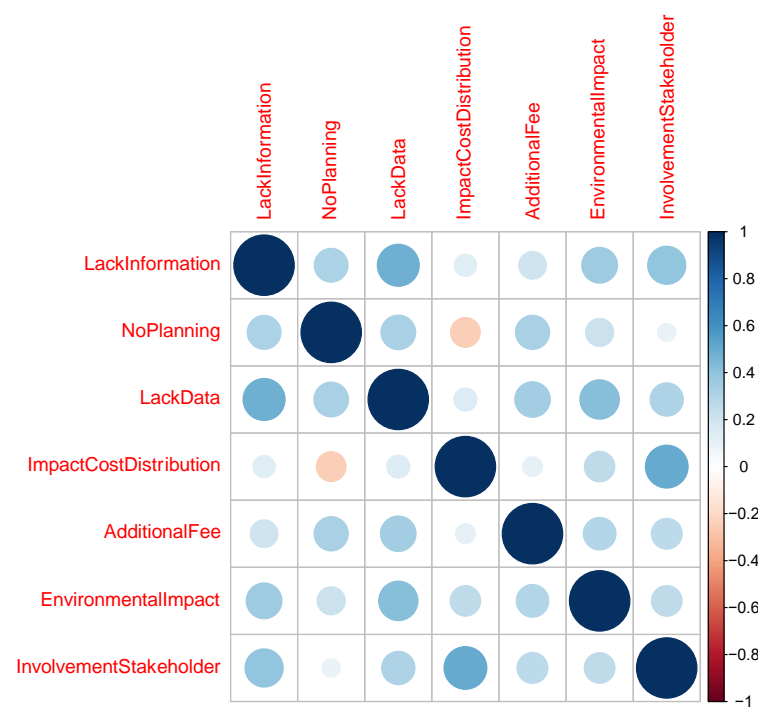

(b)

Figure 4. (a) Correlation coefficients for urban freight transport problems and (b) restriction policies.

Considering the freight restriction measures, the variables analyzed show a weak correlation. We highlight the moderate correlation between the lack of information about the restrictions and the lack of data for planning the restrictions. São Paulo was the first city to implement restrictions in Brazil, which were implemented to improve the quality of the air. In Belo Horizonte, the freight restriction was implemented due to a sequence of fatal accidents involving cars and trucks. Freight restriction is a measure in the Urban Mobility National Plan, in Law 12,587/2012 [30], to improve urban freight transport. However, data to measure the impact of this freight policy are not available.

One consequence of this planning process is observed in the moderate correlation between the lack of involvement of stakeholders and the impact of freight restrictions on the distribution cost because the companies need to complete deliveries. Consequently, a lack of UFT planning and an impact on distribution costs are negatively correlated, i.e., a lack of transportation planning reduces urban mobility and, consequently, cargo mobility, which needs new strategies to deliver products in the city. For example, a freight vehicle restriction forced transport companies to replace vehicles up to 10 tons in size with those of a maximum of 5 tons (Belo Horizonte case) or 2.5 tons (Fortaleza case), increasing the company's fleet and fixed and variable costs to distribute the same volume of products.

Considering the restriction and theft of goods, we asked companies to identify five Brazilian cities where these problems complicate urban delivery. Figure 5 presents these results. In general, performing urban deliveries in larger cities is harder due to freight vehicle restrictions (Figure 5a). The theft of 
goods is a problem also concentrated in larger cities (Figure 5b). In some regions, like Favelas in Rio de Janeiro, some companies apply an additional delivery fee. In Belo Horizonte Metropolitan Area, a police station specializes in cargo theft due to the frequency of incidences of this problem in this area. Thus, Figure 5 depicts these barriers to urban freight transport in Brazil.

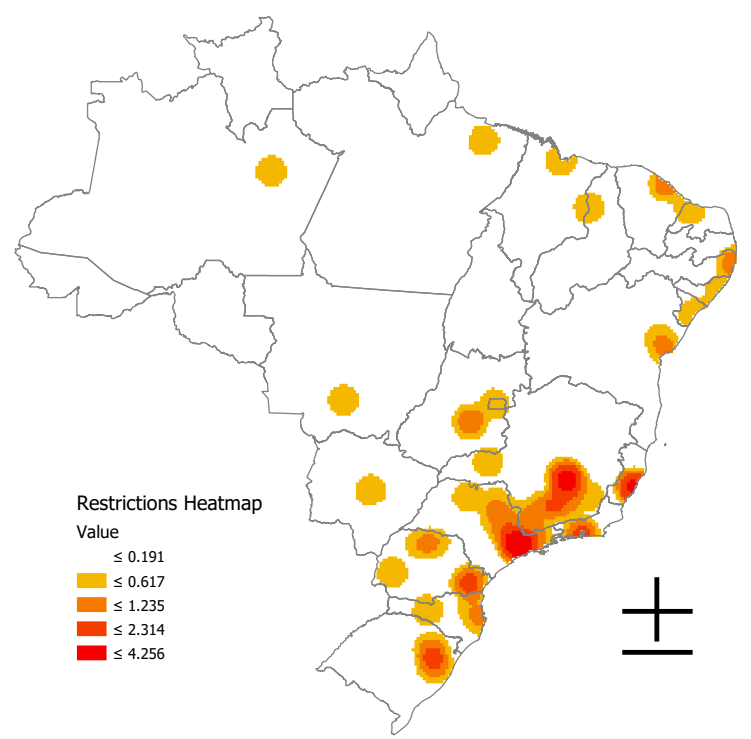

(a)

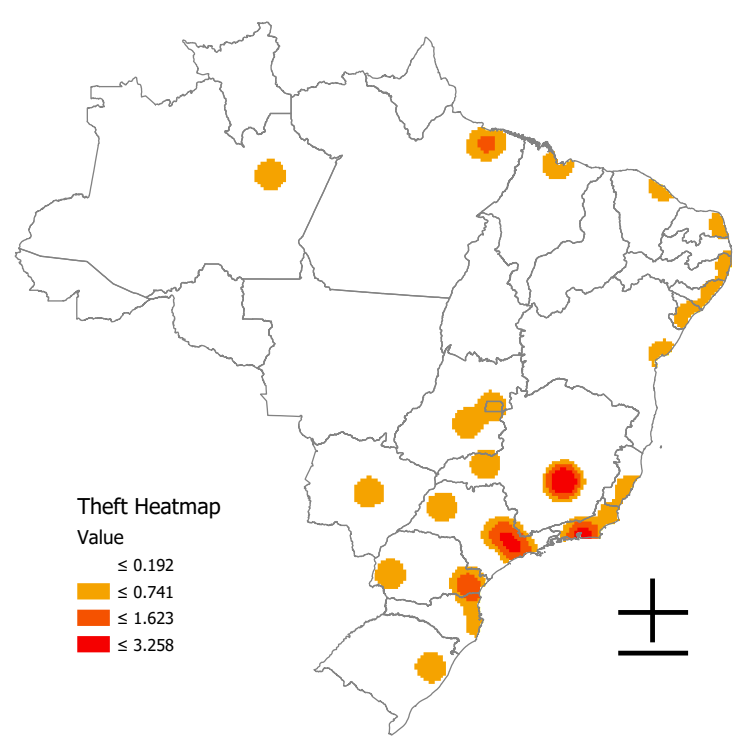

(b)

Figure 5. (a) The heat map of urban freight vehicles restriction and (b) cargo theft in Brazilian cities.

These results show how UFT policies are planned in Brazil: from the experience of certain individuals with little knowledge of the problem. The involvement of stakeholders is still rare in the transportation planning process. However, this paradigm of freight transport planning must be urgently changed, as freight is a vital part of cities for economic development.

\subsection{Barriers and Freight Restriction Analysis}

PCA was used to identify the pattern of similarity between the barriers and the freight restriction measures. Table 3 shows the eigenvalue and the variance of each PC.

Figure 6 depicts the scree plot of the barriers and freight restriction measures, illustrating the eigenvalue ordered from each component called dimension in the plot.

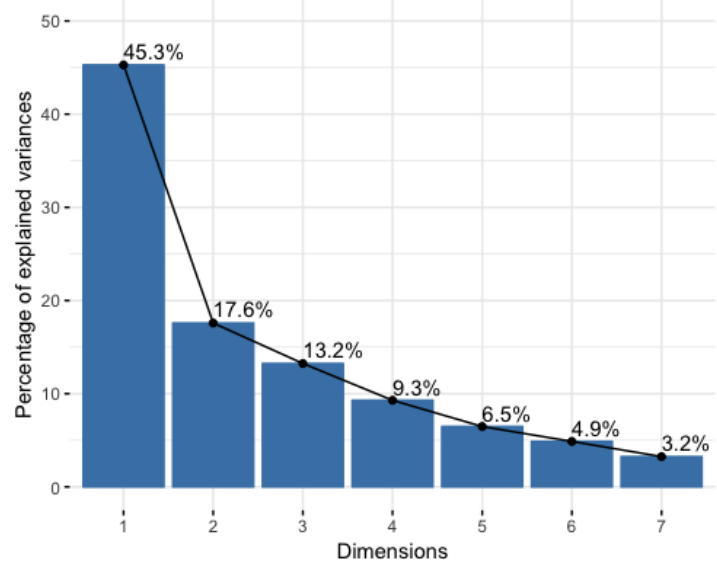

(a)

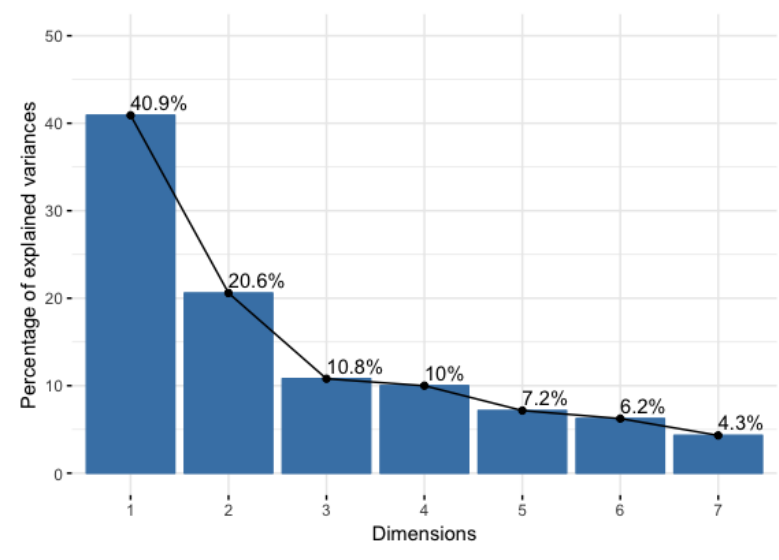

(b)

Figure 6. Scree plot of the (a) barriers and (b) freight restriction measures. 
Figure 7a presents the correlation circle barriers and the representation of the variable on the PC (cos2) results. The restriction, congestion, and availability of $\mathrm{L} / \mathrm{U}$ areas are positively correlated variables. Also, most of the variables have a high $\cos 2$, i.e., variables with a good representation of the PC. The freight vehicle restriction measures (Figure 7b), lack of information, lack of data, no UFT planning process, additional fees, and environmental impacts are correlated differently (environmental impacts are different from the other variables). Finally, in both cases, all the variables point to the right, correlated with this first principal component.

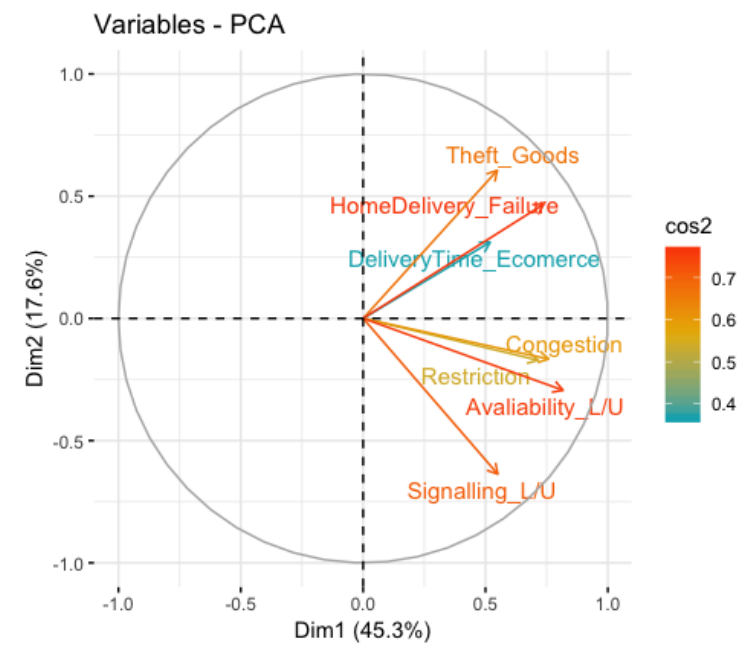

(a)

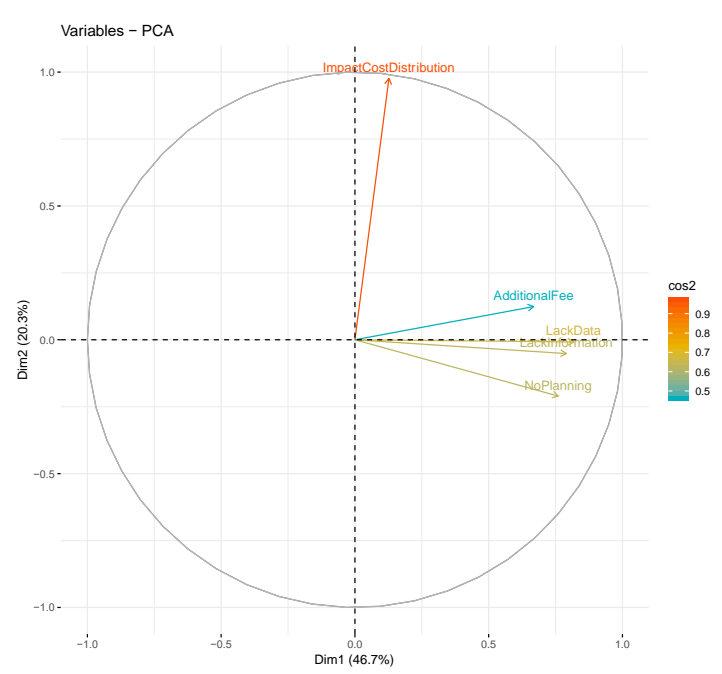

(b)

Figure 7. Correlation circle for (a) barriers and (b) freight restriction measures.

The contribution of each variable to each component is presented in Figure 8a,b. For the barriers related to UFT, restriction, congestion, and availability of L/U areas contribute to PC1 (Dim. 1 in the Figure 8a). Theft of goods and signaling of $\mathrm{L} / \mathrm{U}$ areas contribute to $\mathrm{PC}$, the delivery time of e-commerce goods contributes to PC3, restrictions contribute to PC4, and theft of goods and restrictions contribute to PC 5. For the freight vehicle restriction measures, almost all variables contribute to PC1: lack of information, no planning, lack of data, additional fee restrictions, and environmental impact. The impact of distribution cost and involvement of stakeholders contribute to PC2. The dimension of the contribution of each variable is presented on the axes on the right of Figure 8a,b.

From the PCA results, we identified three main problems related to urban freight transport in Brazilian cities, according to Brazilian transport service provider companies: restriction, congestion, and availability of loading/unloading spaces. These problems are related, in our opinion, to freight policies implemented to avoid having freight vehicles in the city center. Freight restrictions are implemented, in general, to improve car mobility. The consequence of these freight policies is the increase in congestion (due to changing fewer larger freight vehicles to many smaller freight vehicles or to cars to deliver the goods in dense areas). Correspondingly, the number of loading/unloading spaces is insufficient for the number of deliveries required in these areas. The lack of freight parking area generates more congestion.

For the urban freight vehicle restriction measures, the lack of information, no planning, lack of data, additional fee restrictions, and environmental impact are the main issues faced by the urban freight vehicle restriction. The lack of data induces the lack of planning. Brazil does not produce data to analyze urban freight movement. Consequently, urban freight planning is still developing in Brazilian cities. As such, the stakeholders do not have information to operate efficiently in urban centers, which implies that operations are constantly affected. The companies have created fees for delivering to restricted areas. Finally, as stated above, smaller vehicles are being used, increasing the number of cargo vehicles and, consequently, negatively contributing to the environmental impact. 


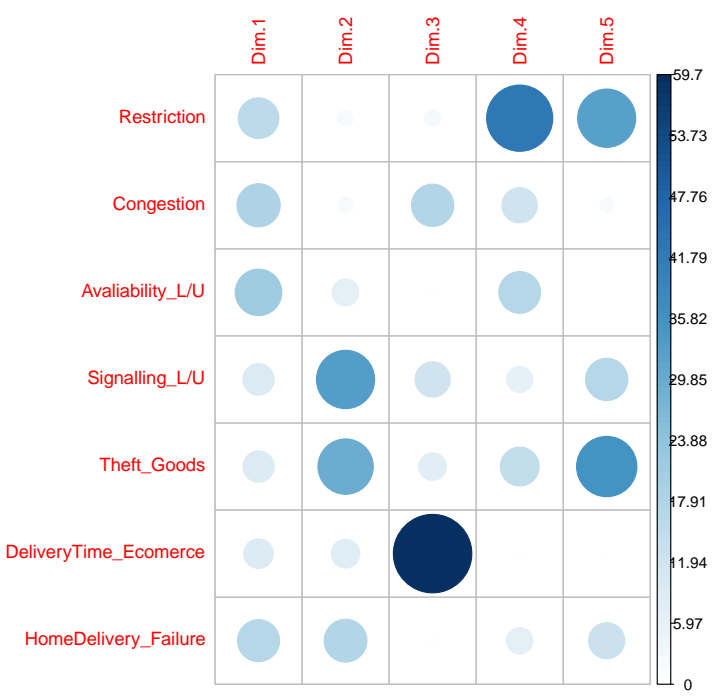

(a)

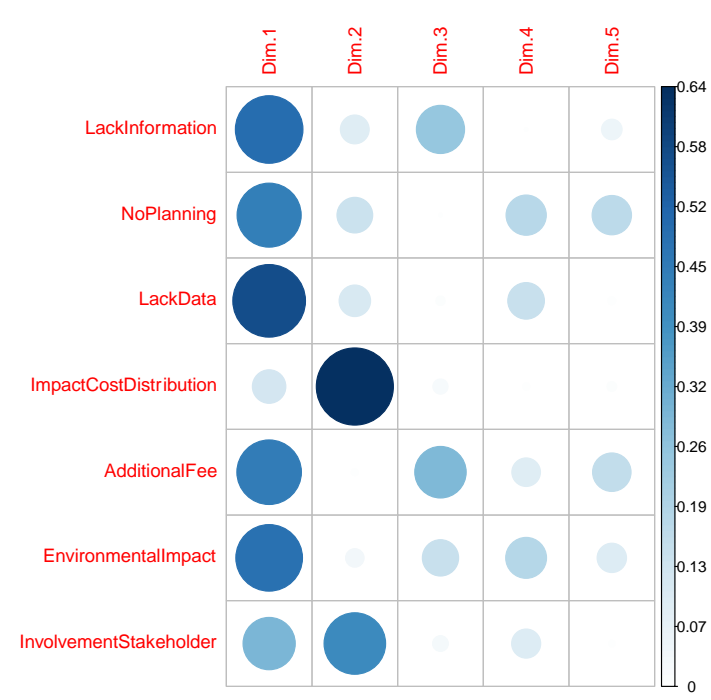

(b)

Figure 8. Correlation plot of contribution variables for each component to (a) barriers and (b) freight restriction measures.

\subsection{Freight Policies Analysis}

Table 4 presents the ranking of freight policy preferences for the preference measure. The urban mobility plan is ranked first amongst the freight policies considered by the companies. Urban mobility plans are mandatory for cities with more than 20,000 inhabitants in Brazil. However, some cities include cargo mobility in these plans [26]. In general, the freight vehicle restriction is the main freight policy proposed by local authorities [26], ranked 11th in our analysis, in contrast to retailers' perceptions on the freight vehicle restriction [10], i.e., some agree and some disagree about the efficacy of this freight policy. With the results presented in this paper, freight vehicle restriction is not a freight solution that should be considered by local authorities to improve cargo mobility.

Table 4. Ranking freight policy preferences.

\begin{tabular}{ccc}
\hline Ranking & Freight Policy & Shannon's Entropy Weight \\
\hline 1 & Urban mobility plan & 0.40 \\
2 & Guidelines to loading/unloading areas & 0.19 \\
3 and 10 & Collaborative delivery & 0.02 \\
4 & Pick-up points or lockers & 0.02 \\
5 & Congestion charge to freight vehicles & 0.01 \\
6 & Cargo bikes & 0.06 \\
7 & Booking in advance loading/unloading areas & 0.05 \\
8 & Truck lanes & 0.12 \\
9 & Electrical vehicles & 0.02 \\
11 & Freight vehicle restriction & 0.05 \\
12 & Off-peak delivery & 0.05 \\
Not chosen & Mini-hubs in urban areas & 0.04 \\
\hline
\end{tabular}

Loading/unloading areas are the second-ranked measure preference. However, this measure is reported to be a challenge to urban freight transport in the literature [10,42,79]. In Brazil, federal law establishes the loading/unloading areas as the infrastructure in urban mobility [10]. However, loading/unloading areas in Brazilian cities are lacking. The lack of enforcement encourages the use of loading/unloading areas for parking for other purposes. The importance of this freight measure to improve the number and availability of these areas in Brazil has been reported [10]. 
Pick-up points are a developing solution in Brazil [63] and could provide one alternative to the failure of home deliveries. The local authorities need to support this solution by providing secure delivery locations. However, Brazilian transport service provider companies need to implement this solution in different areas.

Congestion charges were the solution ranked fifth by the companies. This result is surprising and can be explained by a possible lack of knowledge of companies about the solution. Improvements in cargo mobility are not guaranteed with the implementation of urban tolls. However, this was a freight policy suggested by Campbel et al. [79].

Lastly, we highlight cargo bikes and electric vehicles. Both vehicles are not yet common in Brazil for cargo transportation. However, both can environmentally benefit cargo transportation and can be incorporated into a sustainable urban logistics plan [80].

Another result is the lack of preference for mini-hubs in urban areas. This measure is not usual in large Brazilian cities. Distribution centers are generally located in the peripheral cities of metropolitan areas due to the high cost of land. Thus, despite the benefits of this measure for urban freight transport, it was not recognized by the companies surveyed.

\subsection{Discussion}

The results presented in this paper and previous studies [10] allow us to conclude that Brazilian urban mobility policy does not consider stakeholders' views and, most probably, urban logistics plans will be proposed to comply with the law without the consideration of practical effectiveness and implementation, as is common in the transportation planning process in Brazil.

In general, local authorities create problems instead of focusing on real problems. The local authorities need to articulate and use the law to regulate solutions that create opportunities for the cities and the economy. The measures required to improve urban freight transport must be examined at the micro-level. through examining and understanding the problem, when implementing a suitable solution. Thus, understanding the problem during the planning process must include the involvement of the stakeholders. To do so, the challenging is changing the culture in the transportation planning process by integrating various actors to create an urban logistics plan that generates opportunities for the city. In Brazil, the challenge is to create an urban freight plan in four years (the duration of one political mandate), with simple solutions that are easy to implement.

The literature supports the importance of stakeholder engagement in the planning process [29] to guarantee the efficacy of freight policies. However, conflicting objectives prevent effective engagement. This needs to be changed so that the collective interest will predominate in the development of public policies. Also, stakeholder engagement could be a first step in developing smart cities [81].

\section{Conclusions}

In this paper, we identified the perceptions of the transport service provider companies on barriers and urban freight policies in Brazil. The data were obtained from a web-based survey of 202 Brazilian transport service provider companies.

The main results indicate barriers associated with a lack of urban freight planning process. In order to improve this activity, local authorities need to promote an effective urban mobility plan including cargo mobility in the planning process. On-street loading/unloading areas need to be included as a measure to improve urban freight transport.

For future research, we suggest developing a new vision to planning urban freight transport, integrating stakeholders and different levels of planning. All stakeholders need to participate in the process. Engagement, involvement, and quality of life should be the basic principles of urban freight transport planning. Finally, the freight policies can be effective through the use of planning, monitoring, and evaluation using realistic and standardized indicators. The urban logistics plan should be simple to implement within a single government mandate with an efficient regulatory framework. Then, urban freight transport will contribute to more efficient urban mobility. Also, for future research, we suggest 
discussing the importance of urban freight transport for developing smart cities. We suggest these topics for future research in developing countries.

Author Contributions: Conceptualization, L.K.d.O., P.R.d.S. and P.T.V.d.R.; methodology, L.K.d.O and C.d.O.L.N.; data collection: P.R.d.S. and P.T.V.d.R.; formal analysis, L.K.d.O., C.d.O.L.N., and F.G.F.d.S.; writing-original draft preparation, L.K.d.O.; writing—review and editing, L.K.d.O., P.R.d.S., P.T.V.d.R., C.d.O.L.N., and F.G.F.d.S.

Funding: This research received no external funding.

Acknowledgments: The authors acknowledge the support of the National Council for Scientific and Technological Development (CNPq) and Coordination for the Improvement of Higher-Level Personnel (CAPES). The authors thank all the companies that responded to the survey.

Conflicts of Interest: The authors declare no conflict of interest.

\section{References}

1. Nathanail, E.; Adamosa, G.; Gogasa, M.A. novel approach for assessing sustainable city logistics. Transp. Res. Procedia 2017, 25, 1036-1045. [CrossRef]

2. Behrends, S.; Lindholm, M.; Woxenius, J. The Impact of Urban Freight Transport: A Definition of Sustainability from an Actor's Perspective. Transp. Plan. Technol. 2008, 31, 693-713. [CrossRef]

3. Quak, H.; Balm, S.; Posthumus, B.; Bruening, M. Innovative Solutions for City Logistics: Demonstration and Viability Results. In Proceedings of the European Transport Conference 2012, Glasgow, UK, 8-10 October 2012.

4. World Bank. Word Bank Open Data. 2018. Available online: https://data.worldbank.org (accessed on 15 December 2018).

5. UN. Percentage of Population in Urban and Rural Areas in Brasil. United Nation 2018. World Urbanization Prospects 2018. Available online: https://population.un.org/wup/Country-Profiles/ (accessed on 15 December 2018).

6. Dablanc, L. Goods transportation in large European cities: Difficult to organize, difficult to modernize. Transp. Res. Part A Policy Pract. 2007, 41, 280-285. [CrossRef]

7. Dell'Olio, L.; Moura, J.L.; Ibeas, A.; Cordera, R.; Holguin-Veras, J. Receivers' willingness-to-adopt novel urban goods distribution practices. Transp. Res. Part A Policy Pract. 2017, 102, 130-141. [CrossRef]

8. Kin, B.; Verlinde, S.; Momments, K.; Macharis, C. A stakeholder-based methodology to enhance the success of urban freight transport measures in a multi-level governance context. Res. Transp. Econ. 2017, 65, 10-23. [CrossRef]

9. Rødseth, K. Productivity growth in urban freight transport: An index number approach. Transp. Policy 2017, 56, 86-95. [CrossRef]

10. Oliveira, L.K.; Barraza, B.; Bertoncini, B.V.; Isler, C.A.; Pires, D.R.; Madalon, E.C.; Lima, J.; Vieira, J.G.V.; Meira, L.H.; Bracarense, L.S.F.P.; et al. An overview of problems and solutions for urban freight transport in Brazilian cities. Sustainability 2018, 10, 1233. [CrossRef]

11. Woudsma, C. Freight transportation: The evolving landscape of matters and models. In The Practice of Spatial Analysis: Essays in Memory of Professor Pavlos Kanaroglou; Briassoulis, H., Kavroudakis, D., Soulakellis, N., Eds.; Springer International Publishing: New York, USA, 2019; pp. 189-202. [CrossRef]

12. Lindholm, M. A sustainable perspective on urban freight transport: Factors affecting local authorities in the planning procedures. Procedia Soc. Behav. Sci. 2010, 2, 6205-6216. [CrossRef]

13. Ducret, R.; Gonzalez-Feliu, J. Connecting demand estimation and spatial category models for urban freight: First attempt and research implications. Transp. Res. Procedia 2016, 12, 142-156. [CrossRef]

14. Ducret, R.; Lemarié, B.; Roset, A. Cluster analysis and spatial modeling for urban freight. Identifying homogeneous urban zones based on urban form and logistics characteristics. Transp. Res. Procedia 2016, 12, 301-312. [CrossRef]

15. Castro, R.B.; Merchán, D.; Lima, O.F., Jr.; Winkenbach, M. City Logistics and Clustering: Impacts of Using HDI and Taxe. In City Logistics 2: Modeling and Planning Initiatives; Taniguchi, E., Thompson, R.G., Eds.; ISTE Ltd and John Wiley \& Sons: London, UK, 2018; pp. 131-141. [CrossRef]

16. Lindawati, J.S.; Goh, M.; Souza, R. Collaboration in urban logistics: Motivations and barriers. Int. J. Urban Sci. 2014, 18, 278-290. [CrossRef] 
17. Toilier, F.; Serouge, M.; Routhier, J.-P.; Patier, D.; Gardrat, M. How can urban goods movements be surveyed in a megacity? The case of the Paris region. Transp. Res. Procedia 2016, 12, 570-583. [CrossRef]

18. Lu, F.; Zhao, F.; Cheah, L. Dimensionality Reduction to Reveal Urban Truck Driver Activity Patterns. Transp. Res. Rec. J. Transp. Res. Board 2018, 2672, 81-82. [CrossRef]

19. Carvalho, P.P.S.; Kalid, R.A.; Rodríguez, J.L.M.; Santiago, S.B. Interactions among stakeholders in the processes of city logistics: A systematic review of the literature. Scientometrics 2019, 120, 567-607. [CrossRef]

20. Marcucci, E.; Gatta, V.; Scaccia, L. Urban freight, parking and pricing policies: An evaluation from a transport provider's perspective. Transp. Res. Part A Policy Pract. 2015, 74, 239-249. [CrossRef]

21. Nordtømme, M.E.; Bjerkan, K.Y.; Sund, A.B. Barriers to urban freight policy implementation: The case of urban consolidation center in Oslo. Transp. Policy 2015, 44, 179-186. [CrossRef]

22. Holguín-Veras, J.; Leal, J.A.; Seruya, B.B. Urban freight policy making: The role of qualitative and quantitave research. Transp. Policy 2017, 56, 75-85. [CrossRef]

23. Le Pira, M.; Marcucci, E.; Gatta, V.; Ignacoolo, M.; Pluchino, A. Towards a decision-support procedure to foster stakeholder involvement and acceptability of urban freight transport policies. Eur. Transp. Res. Rev. 2017, 9, 54. [CrossRef]

24. Oliveira, G.F.; Oliveira, L.K. Stakeholder's perception about urban goods distribution solution: Exploratory study in Belo Horizonte (Brazil). Transp. Res. Procedia 2017, 25, 942-953. [CrossRef]

25. Rai, H.B.; van Lier, T.; Meers, D.; Macharis, C. Improving urban freight transport sustainability: Policy assessment framework and case study. Res. Transp. Econ. 2017, 64, 26-35. [CrossRef]

26. Dias, J.M.; Sobanksi, G.B.; Silva, J.E.A.R.; Oliveira, L.K.; Vieira, J.J.V. Are Brazilian cities ready to develop an efficient urban freight mobility plan? URBE Rev. Bras. De Gestão Urbana (Braz. J. Urban Manag.) 2018, 10, 587-599. [CrossRef]

27. Duin, R.V.; Slabbekoorn, M.; Tavasszy, L.; Quak, H. Identifying dominant stakeholder perspectives on urban freight policies: A q-analysis on urban consolidation centres in The Netherlands. Transport 2018, 33, 867-880. [CrossRef]

28. Furquim, T.S.G.; Vieira, J.G.V.; Oliveira, R.L.M. Restrições de carga urbana e desafios logísticos: Percepção de varejistas e motoristas de Sorocaba. Transportes 2018, 26, 142-156. [CrossRef]

29. Lebeau, P.; Macharis, C.; Mierlo, J.V.; Janjevic, M. Improving policy support in city logistics: The contributions of a multi-actor multi-criteria analysis. Case Stud. Transp. Policy 2018, 6, 554-563. [CrossRef]

30. Oliveira, L.K.; Souza, P.R.; Resende, P.T.V.; Oliveira, R.B.; Oliveira, R.L.M. Viewpoint of industries, retailers and carriers about urban freight transport: Solutions, challenges and practices in Brazil. In City Logistics I: New Opportunities and Challenges; Taniguchi, E., Thompson, R.G., Eds.; ISTE Ltd and John Wiley \& Sons: London, UK, 2018; pp. 287-302. [CrossRef]

31. Aljohani, K.; Thompson, R.G. A Stakeholder-Based Evaluation of the Most Suitable and Sustainable Delivery Fleet for Freight Consolidation Policies in the Inner-City Area. Sustainability 2019, 11, 124. [CrossRef]

32. Akgün, E.Z.; Monios, J.; Rye, T.; Fonzone, A. Influences on urban freight transport policy choice by local authorities. Transp. Policy 2019, 75, 88-98. [CrossRef]

33. Gatta, V.; Site, P.D.; Le Pira, M.; Carrocci, C.S. Planning with stakeholders: Analysing alternative off-hour delivery solutions via an interactive multi-criteria approach. Res. Transp. Econ. 2019, 73, 53-62. [CrossRef]

34. Semanjski, I.; Gautama, S. A Collaborative Stakeholder Decision-Making Approach for Sustainable Urban Logistics. Sustainability 2019, 11, 234. [CrossRef]

35. Oliveira, L.K.; Sousa, L.T.M.; Nascimento, C.O.L.; Silva, T.G.C.; Pinto, P.H.G.; Garcia, M.N.; Farias, L.P.; Ferreira, S.; Oliveira, R.L.M.; Jesus, M.C.R.; et al. Sustainable City Logistics Planning: Methods and Applications, Volume 2; Awasthi, A., Ed.; Nova Science Publishers: New York, NY, USA, 2020.

36. Marcucci, E.; Le Pira, M.; Gatta, E.; Inturri, G.; Ignacoolo, M.; Pluchino, A. Simulating participatory urban freight transport policy-making: Accounting for heterogeneous stakeholders' preference and interaction effects. Transp. Res. Part E Logist. Transp. Rev. 2017, 103, 69-86. [CrossRef]

37. Marcucci, E.; Gatta, V.; Le Pira, M. Gamification design to foster stakeholder engagement and behavior change: An application to urban freight transport. Transp. Res. Part A 2018, 118, 119-132. [CrossRef]

38. Bean, W.L.; Joubert, J.W. A systematic evaluation of freight carrier response to receiver reordering behaviour. Comput. Ind. Eng. 2018, 124, 207-219. [CrossRef]

39. Russo, F.; Comi, A. Urban freight transport planning towards green goals: Synthetic environmental evidence from tested results. Sustainability 2016, 8, 381. [CrossRef] 
40. Brasil Law 12,587 from 3 January 2012. Available online: http://www.planalto.gov.br/ccivil_03/_Ato20112014/2012/Lei/L12587.htm (accessed on 30 October 2019).

41. Prata, B.A.; Oliveira, L.K.; Holanda, T.C. Locating on-street loading and unloading spaces by means of mixed integer programming. Transportes 2018, 26, 16-29. [CrossRef]

42. Jaller, M.; Holguín-Veras, J.; Hodge, S. Parking in the City: Challenges for Freight Traffic. Transp. Res. Rec. J. Transp. Res. Board 2014, 2379, 46-56. [CrossRef]

43. Allen, J.; Browne, M.; Woodburn, A.; Leonardi, J. The role of urban consolidation centres in sustainable freight transport. Transp. Rev. 2012, 32, 473-490. [CrossRef]

44. Allen, J.; Browne, M.; Woodburn, A.; Leonardi, J. A review of urban consolidation centres in the supply chain based on a case study approach. Supply Chain Forum Int. J. 2014, 15, 100-112. [CrossRef]

45. Browne, M.; Allen, J.; Leonardi, J. Evaluating the use of an urban consolidation centre and electric vehicles in central London. IATSS Res. 2011, 35, 1-6. [CrossRef]

46. Russo, F.; Comi, A. A classification of city logistics measures and connected impacts. Procedia Soc. Behav. Sci. 2010, 2, 6355-6365. [CrossRef]

47. Duin, J.H.R.; Tavasszy, L.A.; Quak, H.J. Towards E(lectric)-urban freight: First promising steps in the electric vehicle revolution. Trasp. Eur. 2013, 54, 1-19.

48. Taefi, T.T.; Fink, A.; Kreutzfeldt, J.; Held, T. On the profitability of electric vehicles in urban freight transport. In Proceedings of the European Operations Management Association, Dublin, Ireland, 7-12 June 2013.

49. Balm, S.; Moolenburgh, E.; Anand, N.; Ploos van Amstel, W. The Potential of Light Electric Vehicles for Specific Freight Flows: Insights from the Netherlands. In City Logistics 2: Modeling and Planning Initiatives; Taniguchi, E., Thompson, R.G., Eds.; ISTE Ltd: London, UK, 2018; pp. 241-260. [CrossRef]

50. Rizet, C.; Cruz, C.; Vromant, M. The constraints of vehicle range and congestion for the use of electric vehicles for urban freight in France. Transp. Res. Procedia 2016, 12, 500-507. [CrossRef]

51. Lenz, B.; Riehle, E. Bikes for urban freight? Experience in Europe. Transp. Res. Rec. 2013, 2379, 39-45. [CrossRef]

52. Gruber, J.; Kihm, A.; Lenz, B. A new vehicle for urban freight? An ex-ante evaluation of electric cargo bikes in courier services. Res. Transp. Bus. Manag. 2014, 11, 53-62. [CrossRef]

53. Riggs, W. Cargo bikes as a growth area for bicycle vs. auto trips: Exploring the potential for mode substitution behavior. Transp. Res. Part F Traffic Psychol. Behav. 2016, 43, 48-55. [CrossRef]

54. Schliwa, G.; Armitage, R.; Aziz, S.; Evans, J.; Rhoades, J. Sustainable city logistics-Making cargo cycles viable for urban freight transport. Res. Transp. Bus. Manag. 2015, 15, 50-57. [CrossRef]

55. Rudra, M.; Roorda, M. Truck-only lanes on urban arterials: A value of time approach. Procedia Soc. Behav. Sci. 2014, 125, 75-83. [CrossRef]

56. Holguín-Veras, J.; Wang, X.; Sánchez-Díaz, I.; Campbell, S.; Hodge, S.D.; Jaller, M.; Wojtowicz, J. Fostering unassisted off-hour deliveries: The role of incentives. Transp. Res. Part A 2017, 102, 172-187. [CrossRef]

57. Mommens, K.; Lebeau, P.; Verlinde, S.; Lier, T.; Macharis, C. Evaluating the impact of off-hour deliveries: An application of the Transport Agent-Based model. Transp. Res. Part D Transp. Environ. 2018, 62, $102-111$. [CrossRef]

58. Verlinde, S.; Macharis, C. Who is in favor of off-hour deliveries to Brussels supermarkets? Applying Multi Actor Multi Criteria analysis (MAMCA) to measure stakeholder support. Transp. Res. Procedia 2016, 12, 522-532. [CrossRef]

59. Bomtempo, A.P.; Cunha, C.B.; Botter, D.A.; Yoshizaki, H.T.Y. Evaluating Restrictions on the Circulation of Freight Vehicles in Brazilian Cities. Procedia Soc. Behav. Sci. 2014, 125, 275-283. [CrossRef]

60. Dablanc, L.; Montenon, A. Impacts of Environmental Access Restrictions on Freight Delivery Activities. Transp. Res. Rec. J. Transp. Res. Board 2015, 2478, 12-18. [CrossRef]

61. Rotaris, L.; Danielis, R.; Marcucci, E.; Massiani, J. The urban road pricing scheme to curb pollution in Milan, Italy: Description, impacts and preliminary cost-benefit analysis assessment. Transp. Res. Part A Policy Pract. 2010, 44, 359-375. [CrossRef]

62. Morganti, E.; Dablanc, L.; Fortin, F. Final deliveries for online shopping: The deployment of pickup point networks in urban and suburban areas. Res. Transp. Bus. Manag. 2014, 11, 23-31. [CrossRef] 
63. Oliveira, L.K.; Oliveira, R.L.M.; Sousa, L.T.M.; Caliari, I.P.; Nascimento, C.O.L. Analysis of accessibility from collection and delivery points: Towards the sustainability of the e-commerce delivery. URBE Rev. Bras. De Gestão Urbana 2019, 11, e20190048. [CrossRef]

64. Cohen, B.; Munoz, P. Sharing cities and sustainable consumption and production: Towards an integrated framework. J. Clean. Prod. 2016, 134, 87-97. [CrossRef]

65. Tavakol, M.; Dennick, R. Making sense of Cronbach's alpha. Int. J. Med Educ. 2011, 2, 53-55. [CrossRef]

66. Friendly, M. Corrgrams: Exploratory displays for correlation matrices. Am. Stat. 2002, 56, 316-324. [CrossRef]

67. Kulik, V.; Sossa, R. Determining the tourist attractive regions by GIS analysis using heatmaps. Geod. Cartogr. 2018, 44, 22-27. [CrossRef]

68. Kaiser, H.F. An index of factor simplicity. Psychometrika 1974, 39, 31-36. [CrossRef]

69. Kaiser, H.F. A Note on Guttman's Lower Bound for the Number of Common Factors. Br. J. Stat. Psychol. 1961, 14, 1-2. [CrossRef]

70. Jollife, I.T. Principal Component Analysis; Springer: New York, NY, USA, 2002.

71. Peres-Neto, P.R.; Jackson, D.A.; Somers, K.M. How Many Principal Components? Stopping Rules for Determining the Number of Non-Trivial Axes Revisited. Br. J. Stat. Psychol. 2005, 49, 974-997. [CrossRef]

72. Pomerol, J.-C.; Barba-Romero, S. Multicriterion Decision in Management: Principles and Practice; Springer: New York, NY, USA, 2018.

73. Wright, K. Package “Corrgram”. 2018. Available online: https://cran.r-project.org/web/packages/corrgram/ corrgram.pdf (accessed on 15 July 2019).

74. Revelle, W. Package "Psych": Procedures for Psychological, Psychometric, and Personality Research. 2018. Available online: https://cran.r-project.org/web/packages/psych/psych.pdf (accessed on 30 October 2019).

75. Venables, W.N.; Ripley, B.D. Modern Applied Statistics with S; Springer: New York, NY, USA, 2002.

76. Husson, F.; Josse, J.; Le, S.; Mazet, J. FactoMineR: Multivariate Exploratory Data Analysis and Data Mining. 2018. Available online: https://cran.r-project.org/web/packages/FactoMineR/FactoMineR.pdf (accessed on 15 July 2019).

77. Gavião, L.O.; Sant'Anna, A.P.; Lima, G.B.A.; Garcia, P.A.A. Composition of Probabilistic Preferences (CPP). Version 0.1.0. Available online: https://cran.r-project.org/web/packages/CPP/CPP.pdf (accessed on 30 October 2019).

78. Gliem, J.A.; Gliem, R.R. Calculating, Interpreting, and Reporting Cronbach's Alpha Reliability Coefficient for Likert-Type Scales. In Proceedings of the 2003 Midwest Research to Practice Conference in Adult, Continuing, and Community Education, Columbus, OH, USA, 7-12 June 2003.

79. Campbell, S.; Holguín-Veras, J.; Ramirez-Rios, D.G.; González-Calderón, C.; Kalahasthi, L.; Wojtowicz, J. Freight and service parking needs and the role of demand management. Eur. Transp. Res. Rev. 2018, 10, 47. [CrossRef]

80. Matusiewicz, M. Towards Sustainable Urban Logistics: Creating Sustainable Urban Freight Transport on the Example of a Limited Accessibility Zone in Gdansk. Sustainability 2019, 11, 3879. [CrossRef]

81. Vukovic, N.; Rzhavtsev, A.; Shmyrev, V. Smart city: The case study of Saint-Peterburg. Int. Rev. 2019, 1-2, 15-20.

(C) 2019 by the authors. Licensee MDPI, Basel, Switzerland. This article is an open access article distributed under the terms and conditions of the Creative Commons Attribution (CC BY) license (http://creativecommons.org/licenses/by/4.0/). 